This item was submitted to Loughborough's Research Repository by the author.

Items in Figshare are protected by copyright, with all rights reserved, unless otherwise indicated.

\title{
Public health reform: lessons from history
}

PLEASE CITE THE PUBLISHED VERSION

http://www.municipalengineer.com

PUBLISHER

(c) Institution of Civil Engineers

VERSION

VoR (Version of Record)

LICENCE

CC BY-NC-ND 4.0

REPOSITORY RECORD

Fisher, Julie, Andrew P. Cotton, and Brian Reed. 2019. "Public Health Reform: Lessons from History". figshare. https://hdl.handle.net/2134/9918. 
This item was submitted to Loughborough's Institutional Repository (https://dspace.lboro.ac.uk/) by the author and is made available under the following Creative Commons Licence conditions.

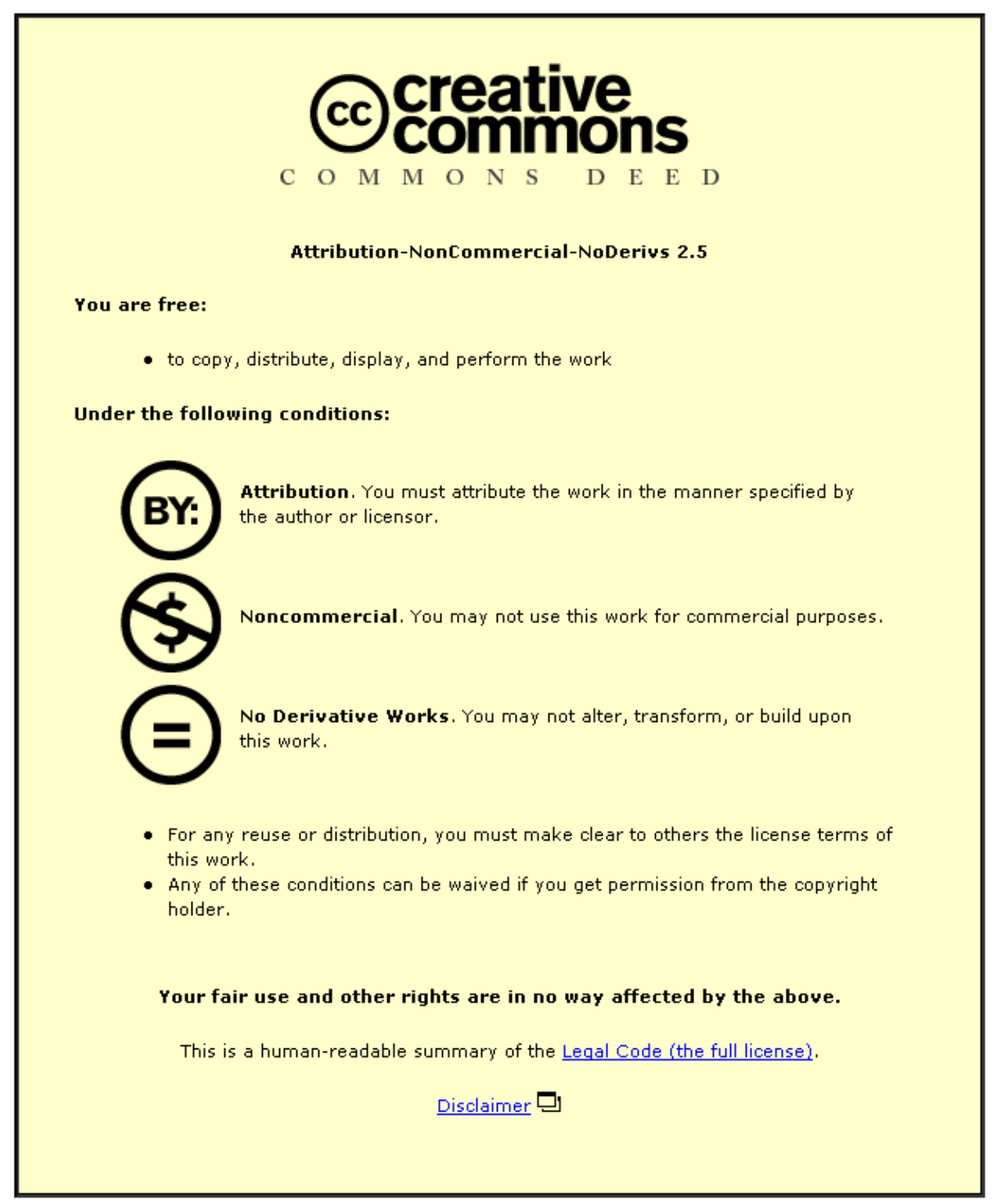

For the full text of this licence, please go to: http://creativecommons.org/licenses/by-nc-nd/2.5/ 


Proceedings of the Institution of
Civil Engineers
Municipal Engineer 159
March 2006 Issue MEI
Pages 3-10
Paper 14447
Received 29/09/2005
Accepted 30/01/2006
Keywords:
developing countries/history/public
health
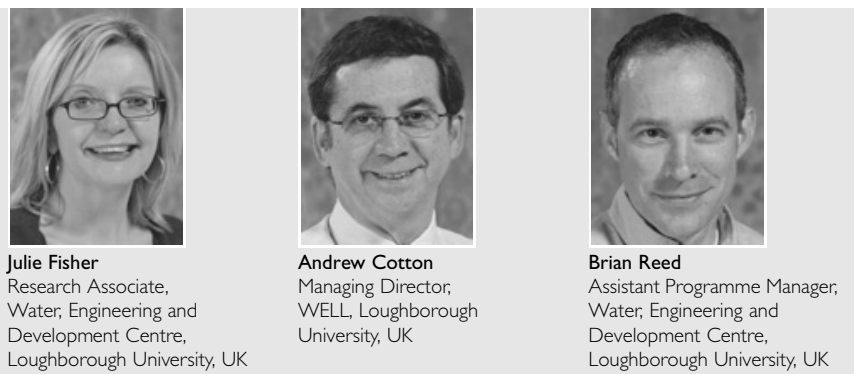

\section{Public health reform: lessons from history}

J. Fisher MA, PhD, A. Cotton PhD, CEng, MCIWEM and B. Reed MSc, CEng, CEnv, MICE, MCIWEM

This is an historical review of the drivers behind the slow development of safe water and sanitation services that took place in Britain during the nineteenth century. Widespread social concern about the living conditions of the poor was combined with more powerful economic incentives to maintain an efficient workforce, and so public health reform was brought about through the joint forces of political reform and specific legislation. Today, the Millennium Development Goals aim to halve by 2015 the one sixth of the world's population that does not have safe water, and the one fifth that has no basic sanitation facilities. An understanding of the historical drivers for change, rather then simply 'good will', will help to ensure that these efforts are based on experience, rather than experiment.

\section{INTRODUCTION}

Learning from history has been identified by the Department for International Development (DFID) as a 'primary task of international development work'. ${ }^{1}$ Its 'Drivers of Change' agenda admits, however, that donors tend to take an ahistorical and apolitical approach. Rather, attention should be paid to the broader political and institutional environment for reform and the incentives and capacity for change that will benefit the poor.

This paper is not an exhaustive and detailed history of the development of water and sanitation services in nineteenth century Britain. Instead, it aims to identify the key lessons that can be learned and applied today to a developing country context from an examination of the historical development of water and sanitation provision in Britain.

\section{I.I. Impacts of socio-demographic change}

The nineteenth century was characterised as a period of unprecedented and rapid population growth in the newly developing industrial towns, together with political change and the emergence of local government institutions. The rapid migration of rural workers to the new manufacturing towns was due to several factors-the loss of agricultural livelihoods with the enclosure of common land, the system of poor relief and the response to the introduction of the factory system. ${ }^{2}$ Population rates of cities increased at the rate of 2.5\% per annum in English and Welsh cities between 1821 and $1831 .^{3}$ For example, London's population rose from 959000 in 1801 to 1655000 in 1831 and to 2807000 by $1861 .^{4}$

Accommodation, built in response to increased demand, provided extremely inadequate living conditions for the urban working classes, housed in cramped tenements, back-to-back and cellar dwellings (see Fig. 1). ${ }^{5}$ In 1840, a quarter of the population in Liverpool lived in overcrowded, unventilated courts and a tenth lived in cellars. An investigation into a cholera outbreak in Newcastle-upon-Tyne in 1854 revealed that half of all working families lived in a single room, having no independent water supply or toilet facilities. ${ }^{6}$

\section{DRIVERS FOR CHANGE}

\section{I. The national concern with public health}

From the 1830s, national concern over the state of working-class living conditions and public health grew. Reporting by Royal Commissions, journalists, social commentators and writers such as Dickens, Gaskell and Engels raised this awareness, ${ }^{7}$ while improved record keeping provided statistical evidence that the number of poor was increasing and they were dying younger. ${ }^{8}$

Although a government was not bound to act on the findings of the many Royal Commissions, public opinion increasingly expected authorities to take action, where previously, government involvement in people's lives had been opposed. ${ }^{9}$ Chadwick's Poor Law Commissioners' Report $(1842)^{10}$ so shocked the nation that a subsequent enquiry was commissioned. The report, which sold 20000 copies, argues for the provision of water supplies, sewerage and better housing for the working classes, making a link which was not commonly made between unsanitary conditions and poor health. Engles wrote ${ }^{11}$

\footnotetext{
These houses of three or four rooms and a kitchen form, throughout England, some parts of London excepted, the general dwellings of the working-class. The streets are generally unpaved, rough, dirty, filled with vegetable and animal refuse, without sewers or gutters, but supplied with foul, stagnant pools instead. Moreover, ventilation is impeded by the bad, confused method of building of the whole quarter, and since many human beings here live crowded into a small space, the atmosphere that prevails in these working-men's quarters may readily be imagined.
}

More was also becoming known about the causes of water- and sanitation-related disease. The new scientific approach was popular with many health and sanitation associations emerging 


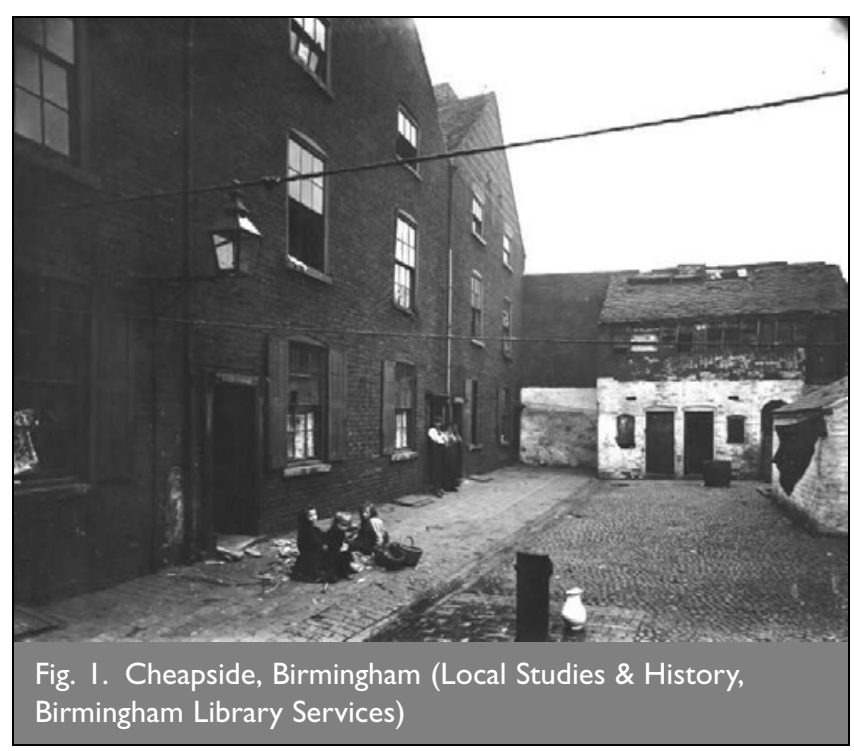

in the 1840 s, to further raise public awareness and to advocate improvements in sewerage, drainage, water supply, air, light and housing.

\subsection{Seminal events}

A crucial factor influencing the political will to bring about improvements in public health was people's own experience of death and disease, or the fear of them. This impacted on all classes, including those with power and influence, as all were potential victims. The Times commented at the time that the disease 'is the best of all sanitary reformers-it overlooks no mistake and pardons no oversight'. ${ }^{12}$

Cholera first arrived in Britain in 1831, soon becoming the country's biggest killer. There were subsequent major outbreaks in 1848, 1853 and 1866, each causing thousands of deaths. The medical profession had little idea about its causes, but the miasmatic theory-in which disease is transmitted by airborne pollution-was prominent. This explanation gained credence due to severe outbreaks of disease during hot summers, when the streets were full of pungent rubbish.
Dr John Snow had always disputed the contention that cholera was an airborne disease. In On the Mode of Communication of Cholera published in $1855,{ }^{13}$ he argued that as a doctor in frequent contact with the disease, he had never contracted it, and furthermore the infection affected the gut before patients felt really ill, therefore it was far more likely that it was ingested. This was confirmed in 1854 when 500 deaths occurred in Soho, London, within ten days. This affected people of all classes in what has become known as the Broad Street Pump Incident. Dr Snow mapped out these cases, thereby implicating a single contaminated well in Broad Street. When the pump handle was removed, the spread of cholera stopped. In spite of these findings, which confirmed Snow's earlier hypothesis, social improvements in Soho were slow to come about, with no reported improvements in living conditions during the following year. ${ }^{14}$

Snow also demonstrated that water drawn from suppliers downstream of the Thames, into which many sewers flowed, caused a death rate 14 times that of water from companies drawing clean water upstream. Although by 1853 , as a result of the 1848 Sewers Act, only 1000 houses remained unconnected to sewers, these same sewers discharged into the Thames leading to extreme unsanitary conditions and stench. The Metropolitan Commission on Sewers could not impose sufficiently high taxes to solve the problem and the Thames became known as the Great Stink. In 1859, water supply intakes were finally moved upstream of sewerage outlets and an intercepting sewer system on the Embankment was built to improve the flow of water (Fig. 2). ${ }^{15}$

\subsection{Public health legislation}

As a result of the growing sanitary reform movement, a series of acts was passed replacing local municipal autonomy with the imposition of duties on local authorities (see Fig. 3). Some of the main legislative measures stipulated regulations relating to issues such as connections to common sewers and drain construction, street paving, drainage and cleaning, lighting, housing standards, slum clearance and the appointment of sanitary inspectors. The 1844 Metropolitan Buildings Act required that all newly constructed buildings within $30 \mathrm{ft}(9 \cdot 14 \mathrm{~m})$ of the common sewer had to have connections to it, with improved

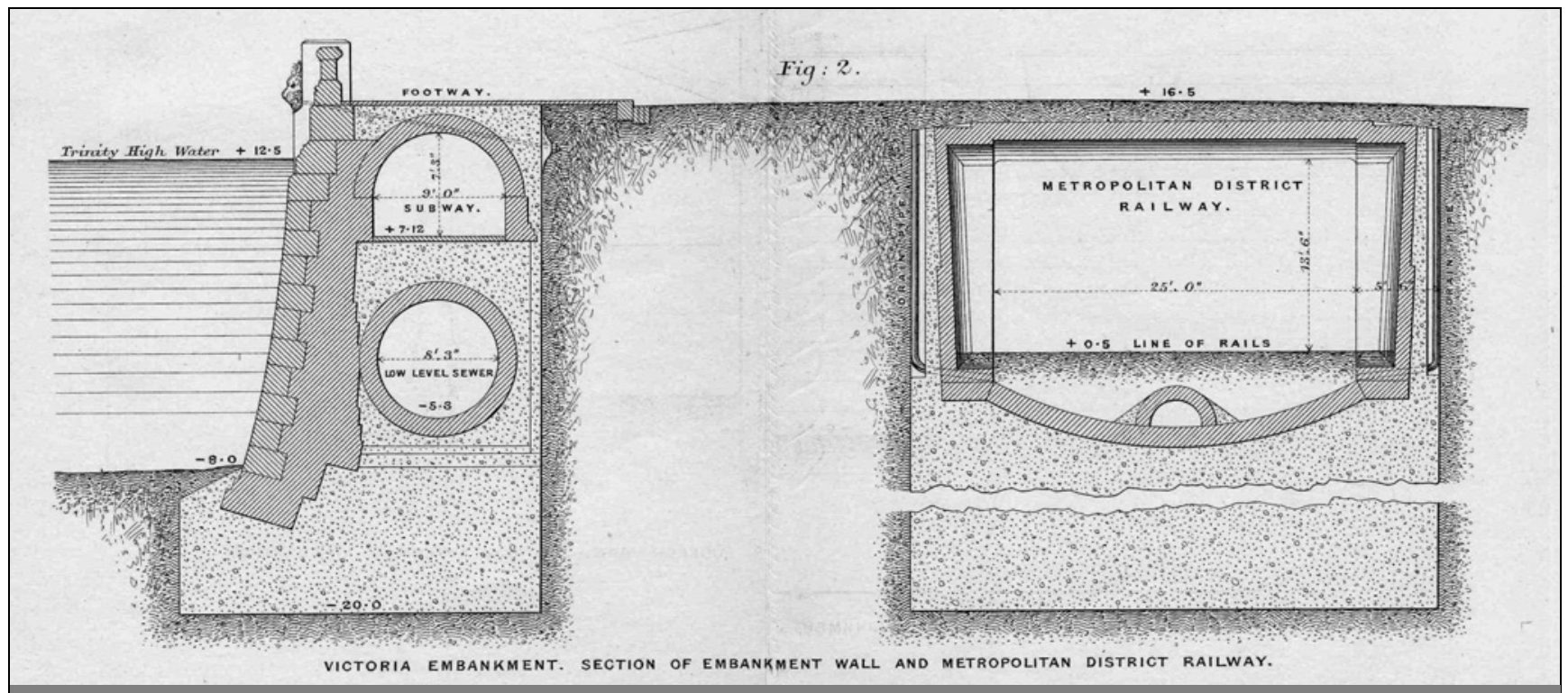

Fig. 2. Section of Thames Embankment, subway and low-level sewers (Institution of Civil Engineers) 


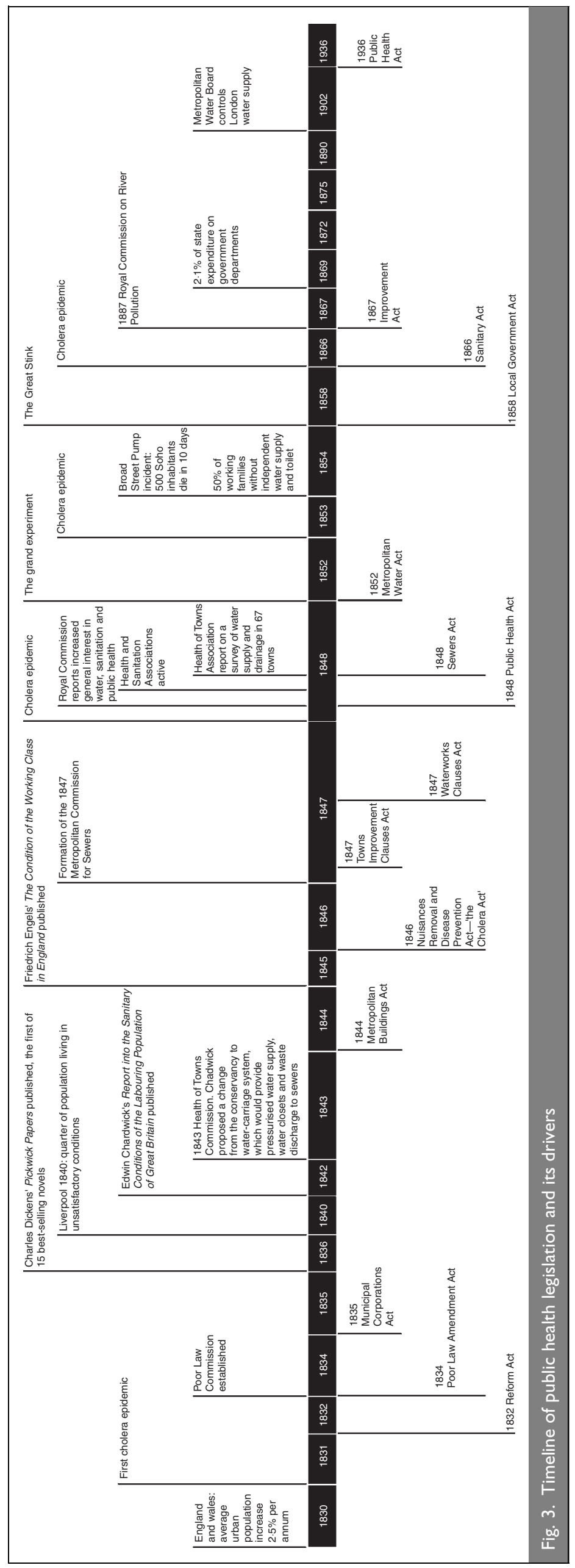


quality of drain construction. ${ }^{4}$ The 1847 Town Improvement Clauses Act legalised the discharge of sewage from sewers into rivers and the sea, and allowed its sale for agricultural purposes. It also encouraged drainage, paving, cleansing and lighting. In 1848 the Public Health Act was the first to create a Central Board of Health with powers to supervise street cleaning, refuse collection, water supply and sewerage disposal. ${ }^{3}$

Still, the rate of improvement was slow and patchy and it was not until the latter half of the century that notable reductions in mortality and morbidity in Britain's cities were seen. ${ }^{2}$ A major restricting factor was that although legislation required household connections to be put in place, there was no direct funding from the Treasury, and the householders themselves often had to bear the costs.

\subsection{Economic concerns}

The level of investment in public health was low, relative to what was known about the social benefits and costs. Williamson ${ }^{2}$ outlines contemporary incentives, such as the suggestion that the required expenditure would be offset by reductions in Poor Law costs. Also the rich were themselves at risk of infection. Chadwick ${ }^{10}$ documented the benefits that would accrue to the poor from improved sanitary conditions. However, they did not willingly pay these initial costs since they were not well informed, their tenancies were short term, and in many cases, they were too poor to pay.

Ultimately the firm economic benefits for the rich derived from a fit workforce were more persuasive than any moral obligation to the needy. Improvements in public health in Wolverhampton, supported by the town's businessmen, were motivated mainly on capitalist rather than humanitarian grounds. ${ }^{16}$ The costs incurred of losing productive workers far outweighed the cost of investing in sanitation and clean water, thereby making good economic sense, as outlined below.

\section{CHANGES IN GOVERNANCE}

\section{I. Laissez faire to state intervention}

Until the mid-nineteenth century, government involvement in public health was minimal, with laissez faire principles being dominant. These were based on the ideas of the economist, Adam Smith, ${ }^{17}$ who advocated free trade, stimulating competitiveness and innovation, leading to economic growth and benefits for all. In terms of social policy, this meant minimal government intervention, ${ }^{18}$ with any notion of public welfare being the responsibility of the local parish. By the mid-nineteenth century, these ideals were deeply entrenched in British society and in 1869 only $2 \cdot 1 \%$ of all state expenditure went on government departments. $^{18}$

Unprecedented population growth outstripped economic growth during the 1800s. For this reason, mid-Victorian government began to move towards a more central interventionist stance on social and economic matters, including public health, to mitigate some of the impacts of uncontrolled capitalism. This state intervention was grudgingly conceded and had a limited impact until the later years of the nineteenth century. It came about more from the need to protect the workings of a free trade economy than from a concern for public welfare, and such provision as existed lay mainly with local authorities rather than central government. ${ }^{18}$

\subsection{Local government reforms}

Fifteen per cent of the urban population in 1830 lived under the rule of corporations-that is, not under county rule-although this did not necessarily translate into effective local government.

Corporations were private rather than public institutions, elected by political factions, concerned mainly with protecting their members' property interests more than the welfare of their citizens. ${ }^{19}$ Such an unaccountable system inevitably resulted in an ad hoc and unsatisfactory response to the problems caused by rapid urbanisation.

Political reform began with the 1832 Reform Act ${ }^{15}$ that redistributed the numbers of representatives and extended the franchise to include those who did not own landed property. A later bill in 1835 required that corporations were elected, although those who could vote were generally self-interested property owners, resulting in low spending on drains and water supply. ${ }^{15}$ Even by 1861 , only 3\% of the population of Birmingham could vote for town council members and thereby influence spending. The Second Reform Act of 1867 gave working-class men the vote, weakening the power of the small property owners and offering the potential for an alliance between newly enfranchised workers and industrialists.

From 1870, investment in public health increased dramatically (Fig. 4). After the 1867 Improvement Act it was possible for local authorities to take out loans at favourable rates to develop services, ${ }^{15}$ repayable over periods from 15 to 60 years depending on the work undertaken. ${ }^{20}$ This encouraged infrastructural improvements and a better water supply and sewerage system. In 1872, a comment by Disraeli, a prominent politician at the time, reflected this change: 'the first duty of a Minister should be the health of the people'. ${ }^{21}$

\subsection{Public and private sector involvement}

Although water companies existed as far back as the 1600s, the turn of the nineteenth century marked the launch of many others, replacing what provision there had been by the church or by philanthropic individuals. Although these companies sometimes improved and extended services, private enterprise failed to adequately supply the poor. Contemporary accounts record that one of the worst problems for the urban poor was a lack of a regular and sufficient water supply. ${ }^{22}$ In Bath, in 1845, there were seven companies supplying water, as well as that supplied by the corporation. There were only three standpipes for use by the poor and these were only supplied at certain times in the morning.

Things turned full circle as the 1835 Municipal Corporations Act and the later Improvement Acts allowed compulsory purchase by civic authorities, such as occurred in Manchester (1847), Leeds (1852) and Bradford (1854). The nine London water providers remained in place until 1902 when London's water finally passed into the hands of the Metropolitan Water Board.

For sanitation, there was a succession of privately funded sewer construction developments. Not until the 1848 Public Health Act were local authorities compelled to implement sanitary law, and 


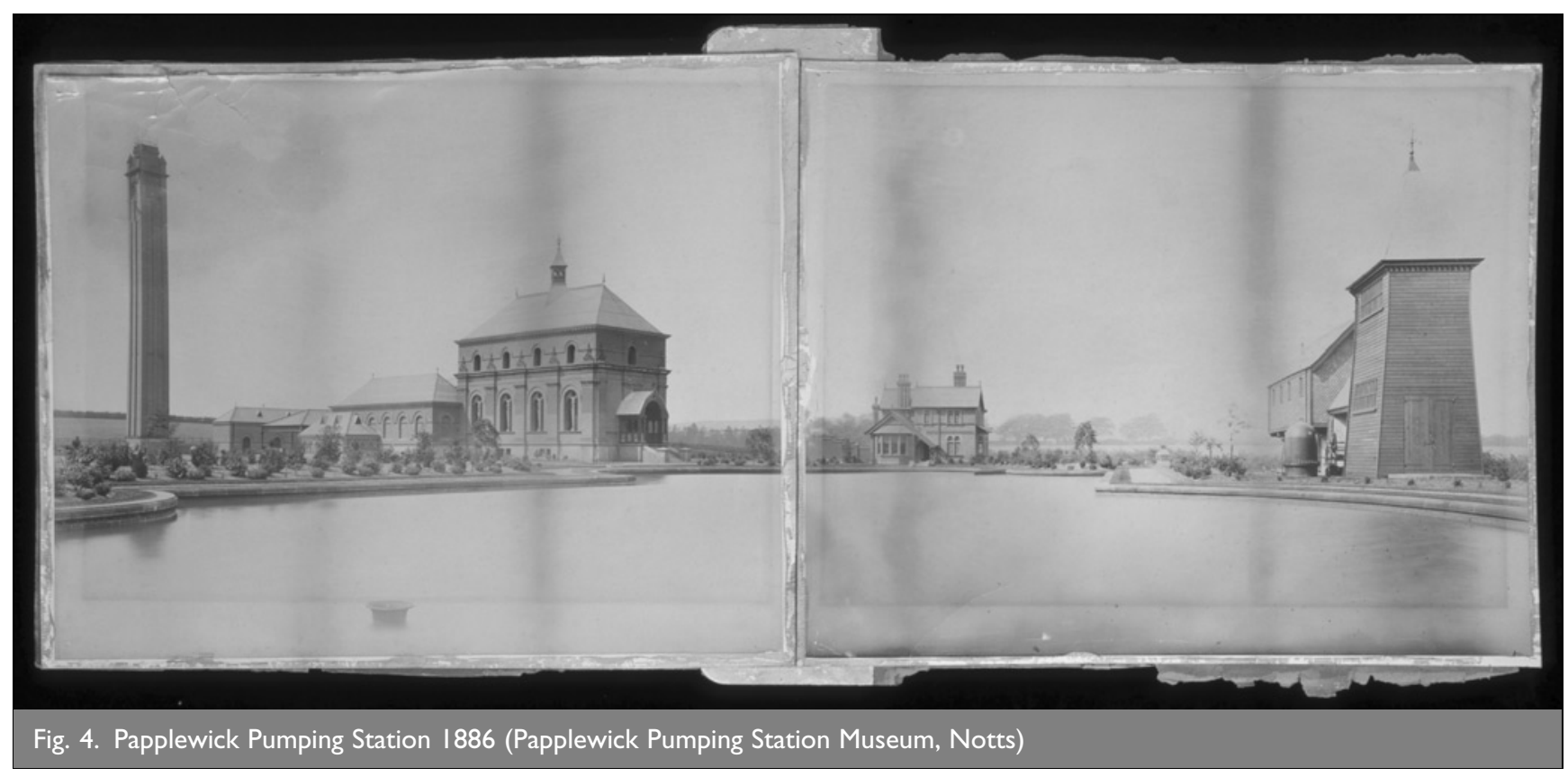

even then the financial burden was on the householder. After 1870 , the level of investment in the financing of sewerage developments rose significantly. The increased wealth of the labouring urban classes also eventually led to higher spending on aspects of their own standard of living, including sanitation.

\section{LESSONS LEARNED}

The following discussion seeks to compare and contrast the historical picture with what is happening today in a developing country context and to see whether historical experience provides any more effective strategies for improvement.

\section{I. The current situation in developing countries}

Some 600 million people in Asia, Africa and Latin America, many of them formerly rural migrants, now live in urban squatter settlements (Fig. 5). ${ }^{23,24}$ Urban population growth rates in middle- and low-income countries were 3.7\% from 1950-1975, $3 \cdot 2 \%$ from $1975-2000$, with a predicted growth to 2030 of $2 \cdot 2 \% .{ }^{25}$ 'Mega-cities' also exist with more than 10 million inhabitants. ${ }^{26}$ As in mid-nineteenth century Britain, these poor urban settlers have no means of providing or demanding

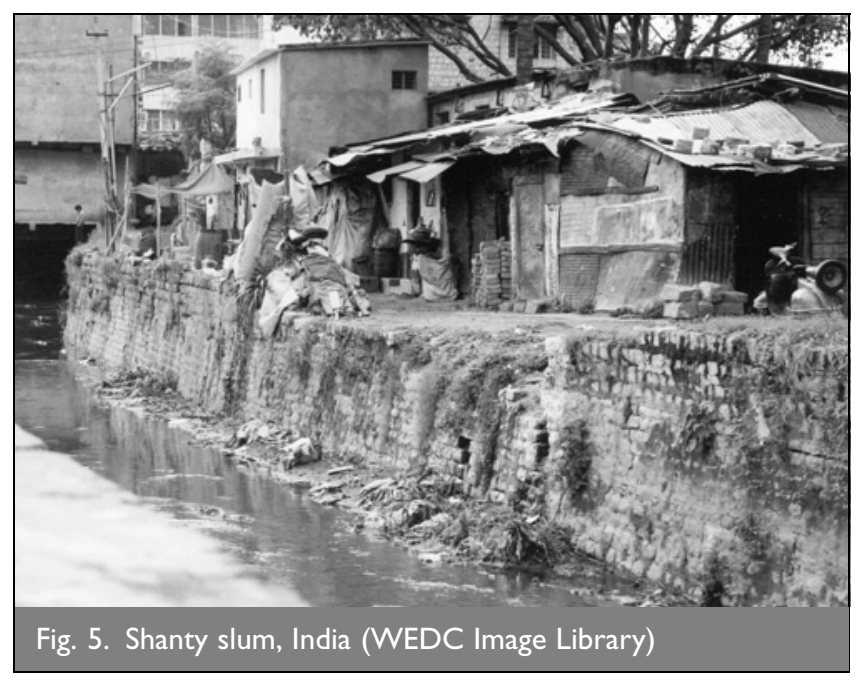

adequate housing and services, ${ }^{27}$ and governments and the construction industry do not keep up with demand. ${ }^{28,29}$ Consequently, informal low-income settlements, slums and shanty towns become the only housing options for many poor people, who have no legal status or voting rights, and are outside of public service provision. ${ }^{30}$ These settlements are not usually connected to sewerage systems, leading to unsanitary conditions which impact on public health (Fig. 6).

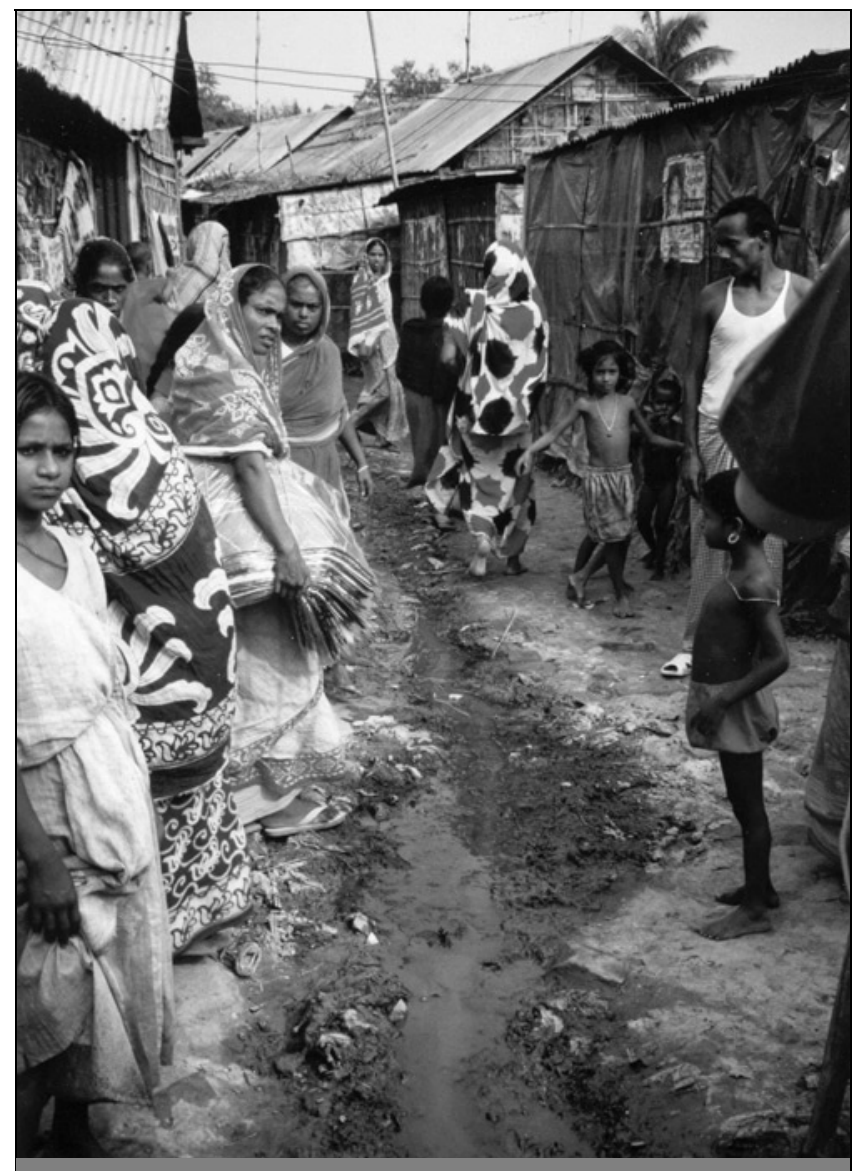

Fig. 6. Urban drainage, Bangladesh (WEDC Image Library) 
Estimates state that 600 million urban dwellers live in conditions that pose threats to health and life due to inadequate water supply, poor sanitation and drainage, ${ }^{31,32}$ with diarrhoea being the largest preventable killer of children under five. ${ }^{33}$ The diseases prevalent in Britain in the past are still common in developing countries, such as dysentery, cholera, typhus fever and typhoid. In 1850s Britain, the national average for infant mortality was 150 per 1000 births, ${ }^{34}$ compared to an average of 121 per 1000 in 2001 across low-income countries today. $^{35}$

There are many echoes of the past in the current public health situation of developing countries, with the same consequences of inadequate hygiene, sanitation and water provision. The World Health Organisation (WHO) suggests that improvements in this area could reduce diarrhoeal deaths by up to two-thirds. ${ }^{36}$

\subsection{Progress towards the Millenium Development Goals}

In September 2000, eight United Nations Millennium Development Goals (MDGs) were agreed upon, designed to alleviate poverty, hunger, illiteracy, environmental degradation and discrimination against women. ${ }^{37}$ Target 10 is to reduce by half the proportion of people without access to safe drinking water and sanitation by 2015. Progress towards this is monitored by WHO and UNICEF, which formed the Joint Monitoring Programme (JMP) for Water Supply and Sanitation ${ }^{38}$ in 1990, to monitor trends in coverage by increasing monitoring capacity in countries and ensuring comparability of indicators.

Five years into the allotted period for improvement, progress towards meeting the target for water has been slow and varies within countries and regions. Progress was made in South Asia, with coverage increasing from 71 to 84\% from 1990 to 2002. In sub-Saharan Africa coverage also increased from 49 to 58\%, though this falls far short of the 75\% coverage required by $2015 .{ }^{39}$ In total, one fifth of the population in developing countries still has no access to safe water and coverage levels are slow to improve (Fig. 7). ${ }^{40}$

For sanitation, 'the world is grossly off-track' in meeting target 10, with 2.6 billion people still lacking basic facilities. ${ }^{38}$ Despite good progress in South Asia, still only a third of its people have access; coverage in sub-Saharan Africa is only $36 \% .{ }^{39}$ It is estimated that at the current rate of progress, this target will be missed by a figure of more than half a billion people. ${ }^{39}$

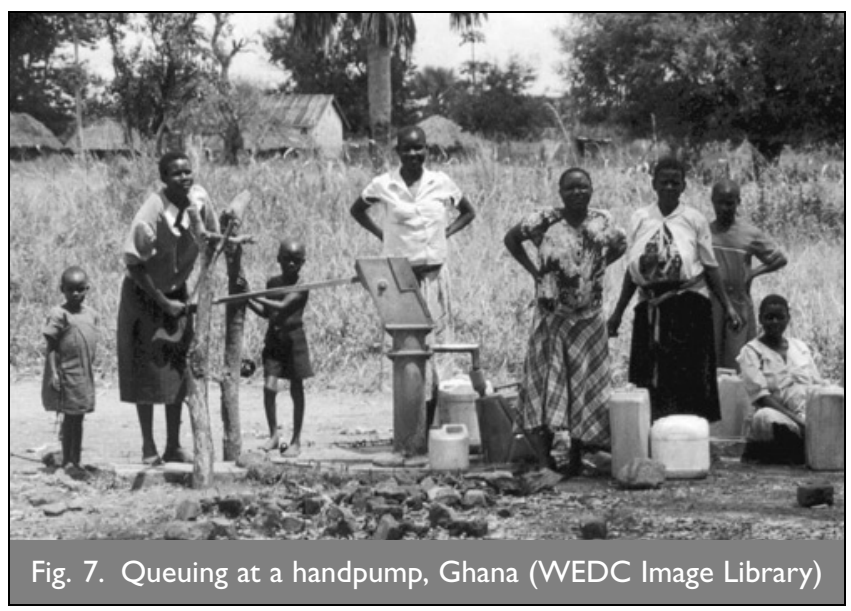

\subsection{Economic drivers for change}

Financing water and sanitation in a developing country context has been a contentious issue since the 1980s. Funding is currently derived from a variety of sources including the public sector, official development assistance loans and grants, small-scale domestic private providers, the international private sector and households and communities themselves. ${ }^{41}$

A recent debate in infrastructure development has been that surrounding the 'rights-based approach'. This means empowering people to influence change and social transformation, while requiring the state to take responsibility for delivering basic rights and service provision to its citizens. ${ }^{42}$ So, on one side of the debate is the 'water and sanitation for all' lobby, who contend that basic facilities should be provided for those who lack them, out of public and donor funds. The counter argument states that affordability of services and willingness to pay are prerequisites to success as facilities financed by donor support may not be sustainable. ${ }^{43}$ As the progress towards target 10 shows, in practice, neither approach has worked.

An alternative perspective is offered by looking back to nineteenth century Britain, as while there was widespread social concern about the conditions endured by the poor, this was insufficient on its own to force the pace of change. It was only when taken in conjunction with powerful economic concerns about the need to have a healthy and therefore productive workforce that sanitary reform gathered pace. There are contemporary parallel examples of the economic costs on national economies of poor sanitation as significant funds are spent on healthcare and medicines, plus there are lost working days due to sickness. ${ }^{23}$ Examples given by UNICEF are costs of 73 million Indian working days lost due to waterborne diseases, and US $\$ 1$ billion lost in ten weeks in tourism and agricultural exports due to a cholera outbreak in the 1990s in Peru. If investments in better water supply and sanitation offer improved health, then this still makes good economic sense today. This offers lessons for latter-day advocacy work in international development. While it may be contentious to opt for playing the 'economic card' of a healthy workforce supplying labour to the economy, experience tells us that it was effective in the past.

\subsection{Governance as a driver for change}

There is currently a very vocal debate about the privatisation of water services, with campaigning organisations in opposition to privatisation of what is seen as a public service. Looking back to the 1800s, there was no consistent approach to financing and a lot of improvements were the responsibility of householders. Involvement in the private sector was complex. Urban water supply was largely in the hands of the private suppliers and was gradually taken over by public bodies, but there remained the problem of supplying the urban poor. ${ }^{44}$ The significant issues were not the ownership of the delivery system, but rather, activities at a household versus a national level. Nationally, public health reform moved ahead in nineteenth century Britain through a combination of broader political reform and specific policy legislation. The process of urban decentralisation was gradual, incorporating greater influence of an expanding electorate with an increase in authority of municipal bodies over public health matters. It was within this legislative and governance context that the operators worked, whether public or private. 
This focus on governance is now emerging as a central tenet in development thinking. ${ }^{45,46}$ DFID has identified delivering the water target through a process of governance reform as a key driver of change. The demand-led approaches to service provision of the 1990s have not generally improved coverage, as political incentives for water governance reform from within wider government institutions were missed. ${ }^{38}$ It is clear that countries 'on track' to achieve the MDG target for water supply have implemented change that is owned and driven not by external agencies but by government, in partnership with users, civil society and the local private sector. ${ }^{38}$ In these cases, high-level policy importantly recognises that water, poverty and economic development are interlinked, ensuring an enabling environment is created and sufficient resources are allocated.

\subsection{The time frame for change}

It is generally accepted that a short-term project-based approach does not deliver sustainable infrastructure services and so longer-term, incremental programmes are advocated, often based around permanent institutions rather than project teams. ${ }^{47}$ However, the changes described in this paper cover a whole century during which a complex mix of political reform, policy legislation and economic drivers of change came together. In the 1930s industrial towns of England and Scotland, George Orwell could still report graphically on their appalling housing and sanitary conditions. ${ }^{48}$ The world is a very different place from Britain in the 1860s, but in its drive to achieve development targets within the next ten years, the international development community would do well to reflect on these early developments in sanitary reform. Relatively quick-fix approaches such as the United Nations International Drinking Water Supply and Sanitation Decade (1981-90), which aimed to provide full coverage of water within ten years, propose unrealistic timescales for change. Recognising and accepting the fact that service delivery is a long-term activity that will not be complete within our lifetime should make sector professionals reassess the problem, especially for the millions who will be born, live and die before an adequate service can be provided. The debate over the provision of services for the poor is a subject that is ongoing, 150 years after Chadwick highlighted their plight.

\section{CONCLUDING REMARKS}

The mid-term assessment of progress towards the water and sanitation targets of the MDGs ${ }^{40}$ highlights the problems with sanitation; the world remains a very long way from achieving them. However, the act of setting these targets has been instrumental in focusing both global and national attention on the problems, particularly the staggering extent of the lack of access to sanitation. As we have seen from the work of Chadwick, Dickens and other commentators in the past, being aware of the appalling living conditions of the poor does not necessarily result in improvements in environmental health.

The road to sanitary reform and improved access in Britain in the nineteenth century took the best part of 100 years and was characterised by an evolutionary process of reforms to governance in the context of strong economic driving forces. There was an increasing sense of ownership of public health issues by government; relevant reforms involved a mix of legislation around decentralisation of authority and responsibility, the respective roles of public and private sector, and specific public health and sanitary measures. Now, as then, it is the poor who are bottom of the list of priorities and it remains crucial to increase their voice. Many of these lessons seem to have been forgotten and are having to be rediscovered. The economic justification for sanitary improvements has to be restated, the roles of public and private sectors debated and appropriate responses to technical problems reinvented. History is not just the realm of the historian, but a valuable resource for the practitioner faced with the same problems in the poorest slums in the world today.

International development trends are now far more focused on the governance agenda and ownership by government of the problems. However, we should reflect that valuable time has perhaps been lost over recent decades by the lack of willingness of the international community to engage across the broad agenda of issues that our history shows were necessary to sanitary reform in Britain. International development has moved from projects to programmes aimed at different groups of actors but without working comprehensively with government to tackle underlying weaknesses. For example, we have seen on the one hand community projects that bear no relation to local government, and on the other support to government agencies that would bring little hope of improved services for the poor.

Projects and programmes have limited time spans; while a time frame of 100 years may be unacceptable in terms of the blight this will have on the lives of millions of people, a project time frame of a year or five years to deliver sustainable services is unrealistic. We need to consider the medium term, to provide the products, plans and people required to deliver public health reform throughout the twenty-first century. The more holistic approach towards working with government on the part of the international community perhaps augers better for the sustainability of improved water and sanitation in middle- and low-income countries. Nevertheless, our history shows there is no quick fix; we must not feign too much surprise in 2015.

\section{REFERENCES}

1. Department for International Development. Drivers of Change. See http://www.dfid.gov.uk/aboutdfid/ organisation/driversofchange.asp (last accessed 09/09/2005).

2. Flinn M. W. Origins of the Industrial Revolution. Longmans, Green and Co., London, 1963.

3. Williamson J. G. Coping with City Growth During the Industrial Revolution. Cambridge University Press, Cambridge, 1990.

4. Halliday S. The Great Stink of London. Sutton Publishing, Gloucs, 1999.

5. Stanbridge H. H. History of Sewage Treatment in Britain. The Institute of Water Pollution Control, Kent, 1976.

6. Cholera Enquiry Commission, 1854. See http:// www.genuki.org.uk/big/eng/NBL/Cholera/ (last accessed 09/09/2005).

7. De Pennington J. Beneath the Surface: Social Reports as Primary Sources. 2001. See http://www.bbc.co.uk/history/ society_culture/welfare/source_bsurface_01.shtml (last accessed 09/09/2005).

8. Cherry G. E. Urban Change and Planning: A History of Urban Development in Britain Since 1750. Foulis, London, 1972. 
9. Borstlap L. Sanitation Provision and Urbanisation: Lessons Learned from the British Industrial Revolution. MSc thesis, Loughborough University, 2002.

10. Chadwick E. Report to Her Majesty's Principal Secretary of State for the Home Department from the Poor Law Commissioners on an Inquiry into the Sanitary Condition of the Labouring Population of Great Britain. Her Majesty's Stationery Office, London, 1842.

11. Engels F. The Condition of the Working Class in England 1844. Sonnenschein \& Co., London, 1892.

12. See http://www.radford.edu/ wkovarik/hist1/ 4industrial.html (last accessed 09/09/2005).

13. Snow J. On the Mode of Communication of Cholera. John Churchill, London, 1855.

14. Summers J. Soho-A History of London's Most Colourful Neighbourhood. Bloomsbury, London, 1989.

15. Daunton M. London's 'Great Stink': the Sour Smell of Success. See www.bbc.co.uk/history/lj/victorian_britainlj/ smell_of_success_1.shtml (last accessed 09/09/2005).

16. Wallis J. A Brief History of Victorian Wolverhampton. 1985. See http://www.scit.wlv.ac.uk/local/victorian.wton.html (last accessed 09/09/2005).

17. Sмітн A. An Enquiry Into the Nature and Causes of the Wealth of Nations. Frome, London, 1812.

18. Evans R. E. Laissez-faire and the Victorians. 2001. See http://www.bbc.co.uk/history/lj/victorian_britainlj/ laissezfaire_1.shtml?site=history_victorianlj_laissez (last accessed 09/09/2005).

19. FRASER D. Power and Authority in the Victorian City. Basil Blackwell, Oxford, 1979.

20. SKeAt W. O. Manual of the British Water Engineering Practice, 3rd edn. Institution of Water Engineers, Cambridge, 1961.

21. Adams S. H. Modern Sewerage Disposal and Hygienics. EAtFN Spon, London, 1930.

22. Records of the Borough of Nottingham 1800-1835. VII. Forman and Sons, Nottingham, 1952.

23. WaterAid/Tearfund. The Human Waste Report. Wateraid, London, 2002.

24. United Nations Environment Programme. Global Environment Outlook. Earthscan Publications, London, 2000.

25. National Research Council. Cities Transformed: Demographic Change and its Implications in the Developing World. National Academies Press, Washington, DC, 2003.

26. Black M. Thirsty Cities: Water, Sanitation and the Urban Poor. WaterAid, London, 1996.

27. Todaro M. P. Economic Development, 7th edn. Addison-Wesley Longman, Harlow, 2000.

28. Beall J. Life in cities. In Poverty and Developments into the 21st century (Allen T. and Thomas A. (eds)). Oxford University Press, Oxford, 2000, pp. 425-442.

29. WAterAid. Private Sector Participation. 2000. See http:// www.wateraid.org.uk/in_depth/in_depth_publications/ 1555.asp (last accessed 05/11/2004).

30. WATERAid. Land Tenure. 2001. See http://www.wateraid.org. uk/site/in_depth/in_depth_publications/default.asp (last accessed 05/11/2004).
31. BlaCK M. Mega-slums: the Coming Sanitary Crisis. 1994. See http://www.wateraid.org.uk/site/in_depth/ in_depth_publications/default.asp (last accessed 05/11/2004).

32. Cairncross S., Hardoy J. E. and Satterthwaite D. The Poor Die Young: Housing and Health in Third World Cities. Earthscan Publications, London, 1990.

33. Jones G., Steketee R. W., Black R. E., Bhutta Z. A. and MorRIS S. S. How many child deaths can we prevent this year? The Lancet, 2003, 362, 9377, July, 65-71.

34. THOMPson B. Infant mortality in nineteenth century Bradford. In Urban Disease and Mortality in Nineteenth Century England (Woods R. and WoodWARd J. (eds)). Batsford Academic and Educational, London, 1984.

35. World BANK. World Development Report 2004: Making Services Work for Poor People. 2004. See http:// econ.worldbank.org/wdr/wdr2004/ (last accessed 09/09/ 2005).

36. World Health Organisation. Healthy Environments for Children Alliance. 2003. See http://www.who.int/heca/ infomaterials/hecanet/en/index3.html (last accessed 09/ 09/2005).

37. United Nations. UN Millennium Development Goals. 2005. See http://www.un.org/millenniumgoals/ (last accessed 09/09/05).

38. See http://www.wssinfo.org/en/welcome.html (last accessed 09/09/2005).

39. UNICEF/World Health ORganisation. Meeting the $M D G$ Drinking Water and Sanitation Target: a Mid-term Assessment of Progress. Environmental Resources Management, London, 2004.

40. Environmental Resources Management. Meeting the Water and Sanitation Millennium Development Goal. Department for International Development, London, 2005.

41. Terry G. and Calaguas B. Financing the Millennium Development Goals for Domestic Water Supply and Sanitation. WaterAid, London, 2002.

42. Department for International Development. Rights-based approaches: overview of the debate. See http:// www.keysheets.org/red_18_rights_based_approaches.html (last accessed 09/09/2005).

43. Cardone R. and Fonseca C. Financing and Recovery. IRC, the Netherlands, 2003.

44. Buer M. C. Health, Wealth and Population in the Early Days of the Industrial Revolution. Routledge and Kegan Paul, London, 1926.

45. Department for International Development. Better Government for Poverty Reduction: More Effective Partnerships for Change. DFID, London, 2003.

46. Department for International Development. Making Government Work for Poor People: Building State Capacity. DFID, London, 2001.

47. Department for International Development. Guidance Manual on Water Supply and Sanitation Programmes. WELL, Loughborough, 1998.

48. ORWell G. The Road to Wigan Pier. Penguin, London, 1989.

\section{What do you think?}

To comment on this paper, please email up to 500 words to the editor at journals@ice.org.uk

Proceedings journals rely entirely on contributions sent in by civil engineers and related professionals, academics and students. Papers should be 2000-5000 words long, with adequate illustrations and references. Please visit www.thomastelford.com/journals for author guidelines and further details. 